\title{
Glycation of glucagon-like peptide-1(7-36)amide: characterization and impaired action on rat insulin secreting cells
}

\author{
F.P.M. O'Harte ${ }^{1}$, Y.H.A. Abdel-Wahab ${ }^{1}$, J.M. Conlon ${ }^{2}$, P. R. Flatt ${ }^{1}$ \\ ${ }^{1}$ School of Biomedical Sciences, University of Ulster, Coleraine, Northern Ireland, UK \\ ${ }^{2}$ Regulatory Peptide Center, Department of Biomedical Science, Creighton University Medical School, Omaha, Nebraska, USA
}

\begin{abstract}
Summary Glucagon-like peptide-1(7-36)amide(truncated GLP-1, tGLP-1) is a potent insulin releasing hormone of the enteroinsular axis. This study has examined glycation of tGLP-1 and effects of such structural modification on insulin secretion. Monoglycated tGLP-1 ( $\mathrm{M}_{\mathrm{r}} 3463.8$, determined by plasma desorption mass spectrometry) was prepared by incubation with glucose under reducing conditions and purified by reversed-phase high performance liquid chromatography. Automated Edman degradation indicated that tGLP-1 was specifically glycated at the amino terminal $\mathrm{His}^{7}$ site. In extracts from mouse small intestine, glycated tGLP-1 represented approximately $14 \%$ of the total tGLP-1 content. Effects of glycated and non-glycated tGLP-1 on insulin secretion were examined using glucose-responsive clonal BRINBD11 cells. In acute (20 min) incubations, $10^{-9} \mathrm{~mol} / \mathrm{l}$ tGLP-1 enhanced insulin release by 2.2 -fold and 1.5 -
\end{abstract}

fold at 5.6 and $11.1 \mathrm{mmol} / \mathrm{l}$ glucose, respectively. In contrast, $10^{-9} \mathrm{~mol} / \mathrm{l}$ glycated tGLP-1 failed to stimulate secretion and insulin output was decreased by $34-73 \%$ following glycation. At $5.6 \mathrm{mmol} / 1$ glucose, non-glycated tGLP-1 $\left(3 \times 10^{-10} \mathrm{~mol} / \mathrm{l}-10^{-8} \mathrm{~mol} / \mathrm{l}\right) \mathrm{ex}-$ erted a 2.3-fold to 3.2-fold increase in insulin secretion compared with controls. The effect of glycated tGLP- 1 at $10^{-9} \mathrm{~mol} / \mathrm{l}$ and $3 \times 10^{-9} \mathrm{~mol} / \mathrm{l}$ was reduced by $51-55 \%$ compared with non-glycated peptide, and its insulinotropic action was effectively abolished. These data indicate that when tGLP-1 is glycated at the amino terminal $\mathrm{His}^{7}$, this modification substantially reduces the glucose-dependent insulinotropic action of the peptide. [Diabetologia (1998) 41: 1187-1193]

Keywords GLP-1(7-36)amide, glycation, insulin secretion, BRIN-BD11 cells.
It has long been recognised that gut hormones have an important role in the regulation of endocrine pancreatic function [1]. Postprandial release of incretins from the intestine, including gastric inhibitory polypeptide (GIP) and glucagon-like-peptide-1(7-36) amide (truncated GLP-1, tGLP-1), stimulates insulin secretion through the enteroinsular axis [2]. This

Received: 6 April 1998 and in revised form: 12 June 1998

Corresponding author: Dr. F. P. M. O'Harte, School of Biomedical Sciences, University of Ulster, Coleraine, N. Ireland, BT52 1SA, UK

Abbreviations: tGLP-1, truncated glucagon-like peptide1(7-36)amide; PD-MS, plasma desorption mass spectrometry; TFA, trifluoroacetic acid; RP-HPLC, reversed-phase high performance liquid chromatography. pathway has been estimated to contribute up to $50 \%$ of the insulin released after ingestion of glucose [2].

The incretin, tGLP-1, is a product of the preproglucagon gene [proglucagon (78-107)amide] and is secreted by L-cells in the intestine after ingestion of carbohydrate, fat or protein $[3,4]$. It is an extremely potent stimulator of insulin secretion as well as somatostatin release but is an inhibitor of glucagon secretion $[4,5]$. In humans, insulin secretion was considerably increased after intravenous infusion of tGLP-1 with glucose [4] and increased twofold when tGLP-1 was given alone [3]. Glucose clearance was also strongly increased by tGLP-1, suggesting that this peptide has an important impact on glucose turnover in humans [6]. Other studies have suggested that part of this action is attributable to direct effects of 
tGLP-1 on glucose uptake and metabolism in muscle [7]. This area is, however, controversial as some workers have not been able to show effects of GLP-1 on glucose metabolism in muscle [8] and differences in action of GLP-1 could exist between rodents and humans $[9,10]$. Despite these difficulties the direct and indirect actions of this hormone on glucose homeostasis have led to the suggestion that tGLP-1 might serve as a potential therapeutic agent for treatment of Type II (non-insulin-dependent) diabetes mellitus $[5,11]$.

It has been found that tGLP-1 stimulates insulin secretion from perfused pig and rat pancreas at concentrations as low as $5 \times 10^{-11} \mathrm{~mol} / \mathrm{l}[3,4]$. Insulinotropic actions of tGLP-1 have been shown also using human and rat islets [3, 4] and insulin secreting cell lines including RINm5F cells [12], HIT-T15 cells [13, 14] and RIN-38 cells [15]. Specific receptors for tGLP-1 have been identified on various rodent betacell lines $[13,16]$ and on human insulinoma cell membranes [17]. The structure of the human pancreatic GLP-1 receptor has been determined followed by its cloning and expression [18]. Specific binding of tGLP-1 to rat beta cells has been shown by receptor autoradiography using ${ }^{125}$ I-labelled tGLP-1 [19].

The present study was carried out to investigate further the insulinotropic actions of tGLP-1 using the recently characterized glucose-sensitive BRINBD11 rat cell line [20]. Recent studies have found that peptide hormones such as proinsulin and insulin can be glycated in vitro and in vivo during synthesis and storage in secretory cells exposed to hyperglycaemia [21-23]. This paper shows that tGLP-1 can be glycated and that monoglycated tGLP-1 displays a greatly decreased insulinotropic action in vitro.

\section{Materials and methods}

Chemicals. We obtained HPLC grade acetonitrile from Rathburn (Walkersburn, Scotland) and sequencing grade trifluoroacetic acid (TFA) from Aldrich (Poole, UK). All water used in these experiments was purified using a Milli-Q, Water Purification System (Millipore Corporation, Millford, Mass., USA). Dextran T-70 activated charcoal, sodium cyanoborohydride, bovine serum albumin fraction $\mathrm{V}$ were purchased from Sigma, Poole, UK. GlycoGel B and iodogen (1,3,4,6-tetrachloro-3 $\alpha, 6 \alpha$-diphenylglycoluril) were obtained from Pierce \& Warriner Ltd., Chester, UK. Na ${ }^{125} \mathrm{I}(100 \mathrm{mCi} / \mathrm{ml})$ for iodination of tGLP-1 was from Amersham International Plc, Aylesbury, UK; rat insulin standard was from Novo Industria, Copenhagen, Denmark and human tGLP-1 was from the American Peptide Company, Sunnyvale, Calif., USA. RPMI 1640 tissue culture medium, foetal calf serum, penicillin and streptomycin were all purchased from Gibco Life Technologies Ltd., Paisley, Strathclyde, UK. All other chemicals used were of the highest purity available.

Preparation of glycated $t G L P-1$. Non-glycated and glycated tGLP-1 were prepared by methods described elsewhere for the preparation of glycated insulin [21]. Briefly, tGLP-1
$(50 \mu \mathrm{g})$ was incubated with glucose $(220 \mathrm{mmol} / \mathrm{l})$ under reducing conditions $\left(\mathrm{NaBH}_{3} \mathrm{CN}\right)$ in $10 \mathrm{mmol} / \mathrm{l}$ sodium phosphate buffer $\mathrm{pH} 7.4$ for $24 \mathrm{~h}$ at $37^{\circ} \mathrm{C}$. A high glucose concentration was included to maximize the yield of glycated tGLP-1 typically resulting in $39.9 \pm 2.3 \%(n=7)$ glycated product (determined from peak areas). Control (non-glycated) tGLP-1 was prepared in exactly the same manner except for the exclusion of glucose from the incubation mixture. Samples were applied to a $(4.6 \times 250 \mathrm{~mm})$ Vydac C-18 218TP54 analytical column (The Separations Group, Hesperia, Calif., USA) and non-glycated and glycated tGLP-1 were separated using linear gradients at a flow rate of $1.0 \mathrm{ml} / \mathrm{min}$. Two major peaks were identified in glycated samples. Samples eluted from HPLC were collected manually from a number of chromatographic runs and nonglycated or glycated tGLP-1 peaks were pooled, taken to dryness under vacuum (Speed-Vac) and reconstituted in $0.12 \%$ (v/v) TFA/water. Non-glycated or glycated tGLP-1 were further purified to homogeneity by repeated HPLC runs on a $(4.6 \times 150 \mathrm{~mm})$ Supelcosil C-8 analytical column (Supelco Inc., Poole. UK). Non-glycated and glycated tGLP-1 were quantified by comparison of peak areas on HPLC (Suplecosil C-8) with a standard curve of known concentrations of tGLP-1.

Plasma desorption mass spectrometry (PD-MS). Samples of non-glycated and glycated tGLP-1 were dissolved in $0.1 \%$ $(\mathrm{v} / \mathrm{v})$ TFA in $20 \% \mathrm{methanol} /$ water and applied to nitrocellulose covered targets using the spincast technique and washed with 3-10 $\mu \mathrm{l}$ of $0.1 \%(\mathrm{v} / \mathrm{v})$ TFA/water [24]. Mass spectra were recorded on a BioIon 20 plasma desorption mass spectrometer (BioIon; Uppsala, Sweden) and spectra were recorded for $1 \times 10^{6}$ primary events. The spectra were calibrated using the $\mathrm{H}^{+}$and $\mathrm{NO}^{+}$ions resulting in a mass precision of $\pm 0.1 \%$.

Structural analysis of glycated insulin by automated Edman degradation. The primary structure of glycated human tGLP1 was determined by automated Edman degradation, using an Applied Biosystems model 471A sequenator modified for online detection of phenylthiohydrantoin amino acids under gradient elution conditions [25]. Standard operating procedures were used (Applied Biosystems Model 471A Protein Sequencers Users Manual), and the detection limit for phenylthiohydrantoins was 0.5 pmol.

Culture of insulin secreting cells. We cultured BRIN-BD11 cells in RPMI-1640 tissue culture medium containing $10 \%$ $(\mathrm{v} / \mathrm{v})$ fetal calf serum, $1 \%(\mathrm{v} / \mathrm{v})$ antibiotics $(100 \mathrm{U} / \mathrm{ml}$ penicillin, $0.1 \mathrm{mg} / \mathrm{ml}$ streptomycin) and $11.1 \mathrm{mmol} / \mathrm{l}$ glucose. The production and characterization of BRIN-BD11 cells are described elsewhere [20]. Cells were maintained in sterile tissue culture flasks (Corning, Glass Works, England) at $37^{\circ} \mathrm{C}$ in an atmosphere of $5 \% \mathrm{CO}_{2}$ and $95 \%$ air using a LEEC incubator (Laboratory Technical Engineering, Nottingham, UK).

Acute tests for insulin secretion. Insulin release from BRINBD11 cells was determined using cell monolayers. The cells were harvested with the aid of trypsin/EDTA (Gibco Life Technologies Ltd., Paisley, Strathclyde, UK), seeded into 24multiwell plates (Nunc, Roskilde, Denmark) at a density of $2.5 \times 10^{5}$ per well, and allowed to attach during overnight culture. Acute studies of insulin release were preceded by $40 \mathrm{~min}$ pre-incubation at $37^{\circ} \mathrm{C}$ in $1.0 \mathrm{ml}$ Krebs Ringer bicarbonate buffer $\left(115 \mathrm{mmol} / \mathrm{l} \mathrm{NaCl}, 4.7 \mathrm{mmol} / \mathrm{l} \mathrm{KCl}, 1.28 \mathrm{mmol} / \mathrm{l} \mathrm{CaCl}{ }_{2}\right.$. $2 \mathrm{H}_{2} \mathrm{O}, \quad 1.2 \mathrm{mmol} / \mathrm{l} \quad \mathrm{KH}_{2} \mathrm{PO}_{4}, \quad 1.2 \mathrm{mmol} / \mathrm{l} \quad \mathrm{MgSO}_{4} \cdot 7 \mathrm{H}_{2} \mathrm{O}$, $10 \mathrm{mmol} / 1 \mathrm{NaHCO}_{3}, 5 \mathrm{~g} / \mathrm{l}$ bovine serum albumin, $\mathrm{pH}$ 7.4) supplemented with $1.1 \mathrm{mmol} / 1$ glucose. Test incubations were performed at $37^{\circ} \mathrm{C}$ using the same buffer supplemented with glucose, non-glycated or glycated tGLP-1 as indicated in the Fig- 
ures. After $20 \mathrm{~min}$ incubation, the buffer was removed from each well and aliquots were stored at $-20^{\circ} \mathrm{C}$ for measurement of insulin by RIA [26].

Occurrence of glycated tGLP-1 in vivo. To evaluate whether glycated tGLP-1 occurs naturally in vivo, small intestines (duodenum, jejunum and ileum) of four overnight fasted adult male Swiss TO mice were pooled and extracted for $3 \mathrm{~h}$ at $4{ }^{\circ} \mathrm{C}$ with 5 volumes of ice-cold acid ethanol $(750 \mathrm{ml}$ ethanol, $235 \mathrm{ml}$ water, $15 \mathrm{ml}$ concentrated $\mathrm{HCl}$ ). The extract was centrifuged for $20 \mathrm{~min}$ at $3000 \mathrm{~g}$ and $4^{\circ} \mathrm{C}$. The supernatant was then concentrated using an AES 1000 Speed-Vac (Savant, Southampton, UK) and stored frozen at $-20^{\circ} \mathrm{C}$. Separation of glycated and non-glycated tGLP-1 in $100 \mu \mathrm{l}$ aliquots of extract was achieved by GlycoGel-B boronate affinity chromatography as described in detail elsewhere [22]. Animals were treated in accordance with Animals (Scientific Procedures) Act 1986.

Concentrations of tGLP-1 in the crude intestinal extract and both glycated and non-glycated peptide fractions were determined by dextran-coated charcoal radioimmunoassay, using rabbit anti-human tGLP-1 antiserum 2135, ${ }^{125}$ I-human tGLP-1 and human tGLP-1 standard. We iodinated tGLP-1 by the solid phase iodogen method and purified it by reversed-phase HPLC as described previously [16]. Crossreactivity of antiserum 2135 (kindly provided by Prof. J.J. Holst, Copenhagen) with glycated and non-glycated tGLP-1 was checked using serial dilutions of peptides over the range $0.04-40 \mathrm{pmol}$. The recovery of tGLP-1 applied to GlycoGel B columns was more than $90 \%$ as assessed by radioimmunoassay. It was also checked that tGLP-1 immunoreactivity in the glycated peptide fraction eluted as a single major peak following reverse-phase high performance liquid chromatography(RP-HPLC) analysis.

Analysis of data. Results are expressed as mean \pm SEM and values were compared using the Student's unpaired $t$-test. Groups of data were considered to be significantly different if $p<0.05$.

\section{Results}

Separation of glycated and non-glycated tGLP-1 by HPLC. Non-glycated and glycated tGLP-1 were separated by RP-HPLC on a Vydac C-18 column (Fig.1). After further purification using a Supelco C8 column, the average molecular masses of non-glycated $\left(\mathrm{M}_{\mathrm{r}}\right.$ 3297.5) and glycated tGLP-1 ( $\left.\mathrm{M}_{\mathrm{r}} 3463.8\right)$ were determined by PD-MS. The difference between the observed molecular masses $(166.3 \mathrm{Da})$ indicated that the glycated peptide contained a single glucitol adduct (164 Da) corresponding to monoglycated tGLP-1.

Peptide sequence analysis of glycated tGLP-1. After automated Edman degradation of monoglycated tGLP-1, the yield of PTH-amino acid in cycle 1 clearly shows that $\mathrm{His}^{7}$ was not present, whereas $\mathrm{Ala}^{8}$ was detected in cycle 2 (yield 225 pmol) indicating that the amino terminal $\mathrm{His}^{7}$ residue was blocked. A strong signal was detected for PTH-derivatives in the remaining cycles including cycles 20 and 28 which represented lysine residues (Table 1). This evidence combined with the data from mass spectrometry clearly indicates that tGLP-1 is glycated at the amino

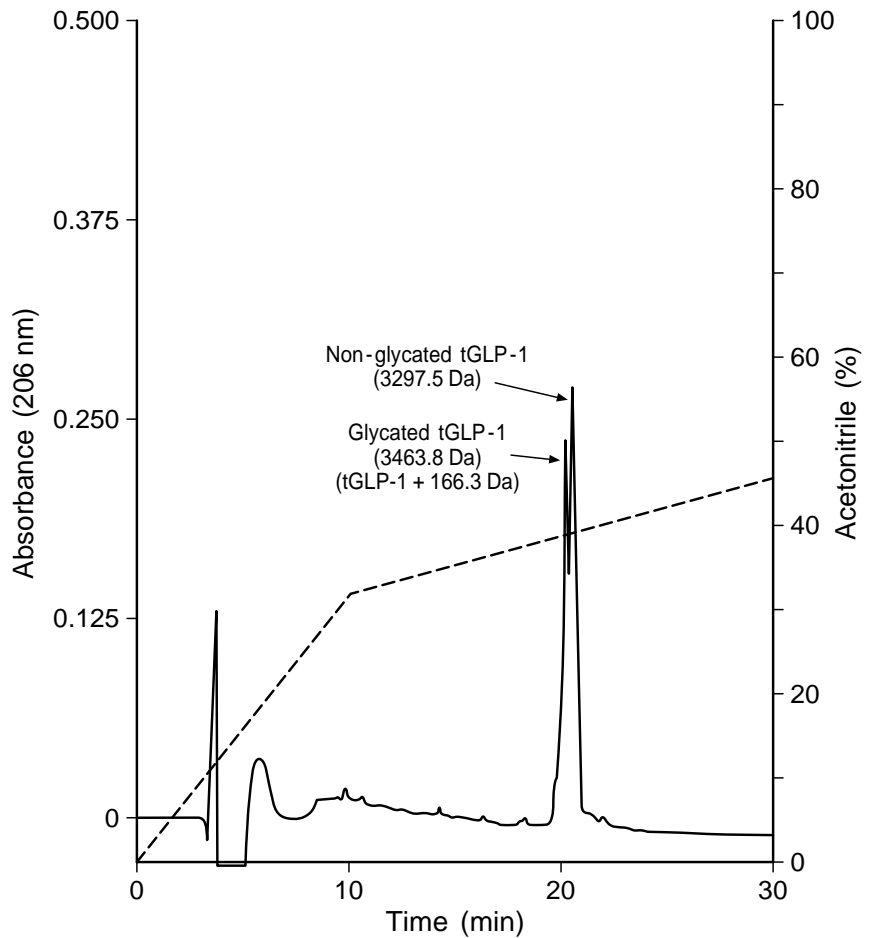

Fig. 1. HPLC separation of tGLP-1 and glycated tGLP-1 on a Vydac C-18 column $(4.6 \times 250 \mathrm{~mm})$. Glycated and non-glycated fractions were separated using linear gradients $0 \%$ to $31.5 \%$ acetonitrile over $10 \mathrm{~min}$ followed by $31.5 \%$ to $45.5 \%$ over $20 \mathrm{~min}$. Two major peaks were collected manually and the molecular masses of the eluted peptides were determined by PD-MS following purification to homogeneity. The observed molecular masses are indicated in parenthesis

terminal $\mathrm{His}^{7}$ residue. The N-terminally glycated tGLP-1 and the non-glycated tGLP-1 were used for subsequent insulin secretion studies.

Effect of glucose, $t G L P$ and glycated $t G L P-1$ on insulin secretion from BRIN-BD11 cells. Glucose induced a significant stepwise (1.6-fold to 2.4-fold) stimulation of insulin secretion from BRIN-BD11 cells at 3.0 to $16.7 \mathrm{mmol} / 1$ glucose compared to incubations without glucose $(0 \mathrm{mmol} / \mathrm{l})$. Addition of $10^{-9} \mathrm{~mol} / \mathrm{l}$ non-glycated tGLP-1 significantly enhanced insulin release by 2.2 -fold and 1.5 -fold at $5.6 \mathrm{mmol} / \mathrm{l}$ and $11.1 \mathrm{mmol} / 1$ glucose, respectively. In contrast, $10^{-9}$ $\mathrm{mol} / \mathrm{l}$ glycated tGLP-1 failed to stimulate insulin release above control values (Fig.2). It appears that tGLP-1 was most effective as an insulinotropic agent at $5.6 \mathrm{mmol} / \mathrm{l}$ glucose and shows a progressive decrease in effectiveness as the concentration of glucose increases. This is in keeping with previous findings on the action of GLP-1 [27-29] where the insulinotropic actions of this peptide were found to be stronger just above normoglycaemic glucose concentrations. Insulin output was decreased by $34-73 \%$ compared with non-glycated tGLP-1 at 5.6-16.7 mmol/1.

Concentration-dependency studies conducted at $5.6 \mathrm{mmol} / \mathrm{l}$ glucose showed a significant 2.4-fold to 
Table 1. Automated Edman degradation of tGLP-1

\begin{tabular}{llc}
\hline Cycle number & Amino acid & Yield $(\mathrm{pmol})^{\mathrm{a}}$ \\
\hline 1 & His & ND \\
2 & Ala & 225 \\
3 & Glu & 174 \\
4 & Gly & 197 \\
5 & Thr & 54 \\
6 & Phe & 184 \\
7 & Thr & 49 \\
8 & Ser & 21 \\
9 & Asp & 86 \\
10 & Val & 116 \\
11 & Ser & 20 \\
12 & Ser & 24 \\
13 & Tyr & 84 \\
14 & Leu & 51 \\
15 & Glu & 43 \\
16 & Gly & 78 \\
17 & Gln & 81 \\
18 & Ala & 57 \\
19 & Ala & 64 \\
20 & Lys & 33 \\
21 & Glu & 31 \\
22 & Phe & 36 \\
23 & Ile & 34 \\
24 & Ala & 29 \\
25 & Trp & 13 \\
26 & Leu & 27 \\
27 & Val & 16 \\
28 & Lys & 16 \\
29 & Gly & 18 \\
30 & Arg & 14 \\
\hline
\end{tabular}

${ }^{a}$ The detection limit for phenylthiohydrantoin amino acids was 0.5 pmol. ND not detected

3.2-fold stimulation of insulin secretion by non-glycated tGLP-1 from BRIN-BD11 cells at concentrations between $3 \times 10^{-10} \mathrm{~mol} / \mathrm{l}$ and $10^{-8} \mathrm{~mol} / \mathrm{l}$ (Fig. $3 \mathrm{a}$ ). At $5.6 \mathrm{mmol} / \mathrm{l}$ glucose, glycated tGLP-1 stimulated insulin secretion by 2.6 -fold only at $10^{-8} \mathrm{~mol} / 1$. Comparison with the insulin releasing potency of non-glycated tGLP-1 showed that glycation resulted in a $51-55 \%$ decrease of activity at concentrations of $10^{-9} \mathrm{~mol} / \mathrm{l}$ and $3 \times 10^{-9} \mathrm{~mol} / \mathrm{l}$. A similar pattern was evident at $16.7 \mathrm{mmol} / \mathrm{l}$ glucose (Fig. $3 \mathrm{~b}$ ). Whereas tGLP-1 stimulated insulin secretion by 1.4 -fold to 1.5 -fold at $10^{-9}, 3 \times 10^{-9}$ and $10^{-8} \mathrm{~mol} / \mathrm{l}$, glycated tGLP-1 failed to stimulate insulin secretion at any concentration tested. Glycated tGLP-1 showed $48-63 \%$ reduced insulinotropic activity compared with non-glycated tGLP-1 at $3 \times 10^{-10} \mathrm{~mol} / \mathrm{l}, 10^{-9}$ $\mathrm{mol} / \mathrm{l}$ and $10^{-8} \mathrm{~mol} / \mathrm{l}$.

Crossreactivity of GLP-1 antiserum with glycated tGLP-1 and occurrence of glycated peptide in mouse intestines. The extract of intestines contained approximately 32 pmol tGLP-1/g tissue as determined by radioimmunoassay (Fig. 4 a). Boronate affinity chromatography separation showed that approximately $14 \%$ of total tGLP-1 immunoreactivity eluted as the glycated peptide. The side viewing antiserum used

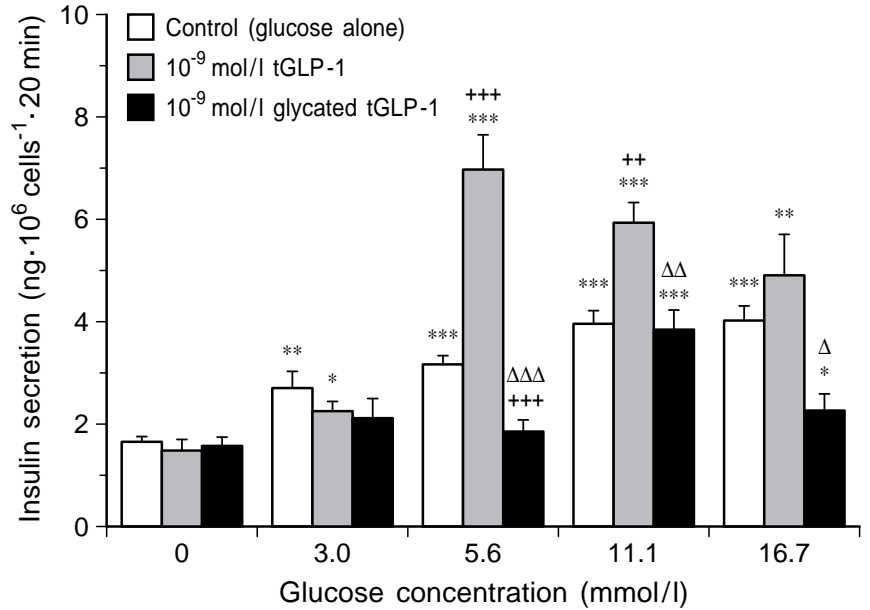

Fig. 2. The effects of glucose and $10^{-9} \mathrm{~mol} / \mathrm{l}$ tGLP-1 or glycated tGLP on insulin release from BRIN-BD11 cells. After 40 min of pre-incubation, the effects of glucose in the absence and presence of $10^{-9} \mathrm{~mol} / \mathrm{l}$ peptide were tested during $20 \mathrm{~min}$ incubation. Values are means \pm SEM for 6 separate observations. ${ }^{*} p<0.05,{ }^{* * *} p<0.01,{ }^{* * * *} p<0.001$ compared with $0 \mathrm{mmol} / \mathrm{l}$ glucose alone. $\Delta p<0.05, \Delta \Delta p<0.01, \Delta \Delta \Delta p<0.001$ compared with non-glycated tGLP-1 at the same glucose concentration. ${ }^{++} p<0.01,{ }^{+++} p<0.001$ compared with the same glucose concentration without tGLP-1

(2135) gives valid measures of glycated and non-glycated tGLP-1 as shown by parallel serial dilution curves (Fig. 4 b).

\section{Discussion}

This study has shown that tGLP-1 [PG (78-107)amide] is a potent glucose-dependent stimulus for insulin secretion from BRIN-BD11 cells. This recently described cell line, derived from the electrofusion of rat beta cells with immortal RINm5F cells, has intact glucose sensitivity and responsiveness to agents affecting adenylate cyclase, phospholipase $\mathrm{C}$ or intracellular $\mathrm{Ca}^{2+}$ [20]. These properties suggest that BRIN-BD11 cells are well suited to studies of the actions of natural and chemically modified gut peptides on insulin secretion.

Although the subject of numerous investigations, the mechanism of action of tGLP-1 on insulin secretion is not fully elucidated $[12,14,30,31]$, but tGLP1 receptors have been identified on islets and clonal beta cells $[16,30]$. These receptors are coupled to adenylate cyclase by a stimulatory G-protein leading to generation of cyclic AMP. There is, however, evidence that tGLP-1 also affects generation of inositol phospholipids, activity of beta-cell ion channels and cytosolic $\mathrm{Ca}^{2+}$ [31-33]. The complex nature of these actions on different signal transduction pathways in the beta cell probably underlies the apparent ability of tGLP-1 to restore glucose sensitivity to dysfunctional insulin secreting beta cells such as in non-insu- 
A
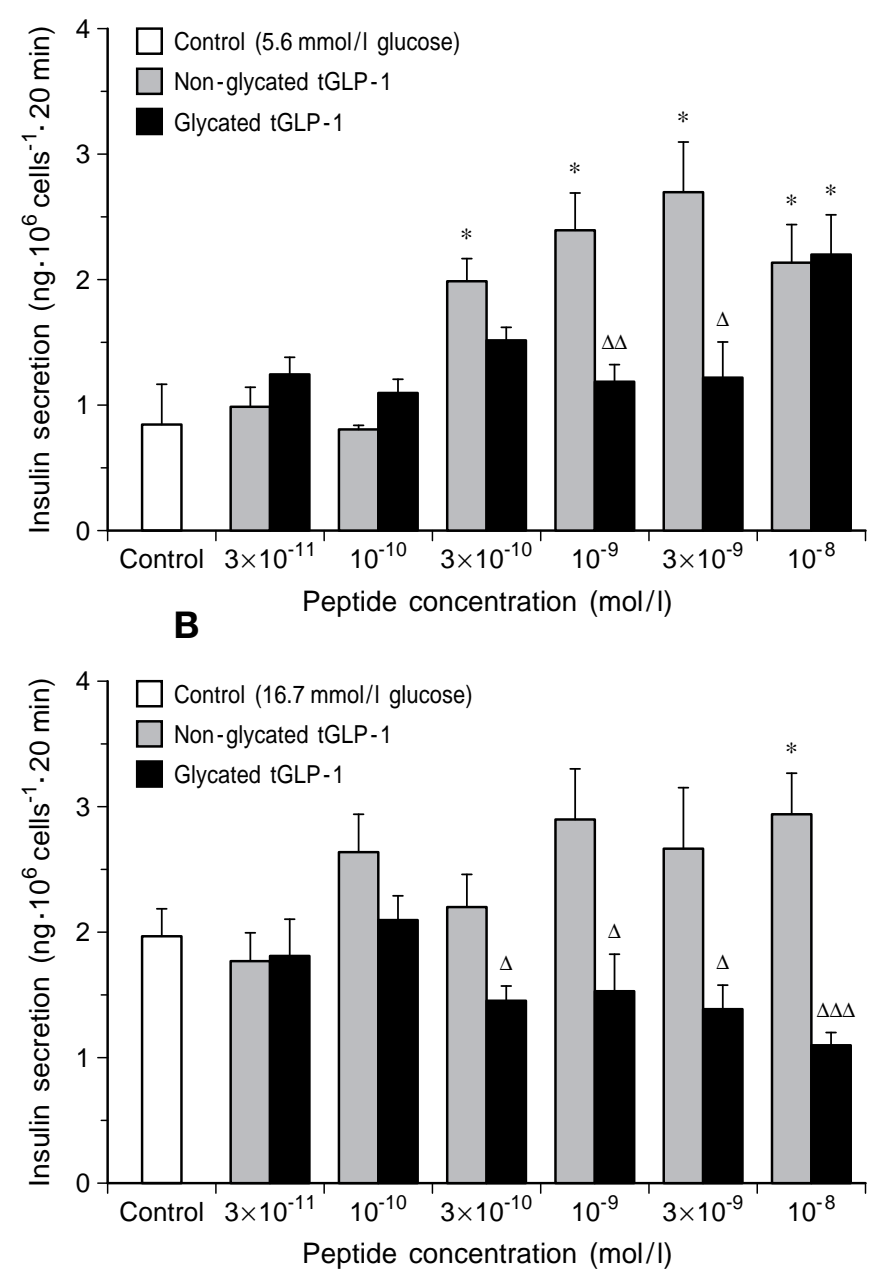

Fig. 3. The effects of various concentrations of tGLP-1 or glycated tGLP-1 on insulin release from BRIN-BD11 cells incubated at (A) $5.6 \mathrm{mmol} / 1$ glucose and (B) $16.7 \mathrm{mmol} / \mathrm{l}$ glucose. After $40 \mathrm{~min}$ of pre-incubation, the effects of various concentrations of peptide $\left(3 \times 10^{-11}\right.$ to $\left.10^{-8} \mathrm{~mol} / \mathrm{l}\right)$ were tested during a $20 \mathrm{~min}$ incubation period. Values are means \pm SEM for 6 separate observations. ${ }^{*} p<0.05$, compared with control (5.6 or $16.7 \mathrm{mmol} / 1$ glucose alone). $\Delta p<0.05, \Delta \Delta p<0.01$, $\Delta \Delta \Delta p<0.001$ compared with non-glycated tGLP-1 at the same concentration

lin-dependent diabetes [34, 35]. Further investigations would be required to determine if the differences in the biological activity of the glycated and nonglycated peptides observed in the present study, arise as a result of changes at the level of beta cell receptor binding or at the level of post-receptor cellular events.

Although tGLP-1 is generally regarded as a glucose-dependent insulinotropic peptide [1], other studies have noted potent insulinotropic effects of tGLP-1 at moderately raised rather than high glucose concentrations [27-29]. It has been shown that tGLP1 also inhibits glucagon secretion in rats more potently at low rather than high glucose levels $[28,36]$. Consistent with these observations, this study indicates
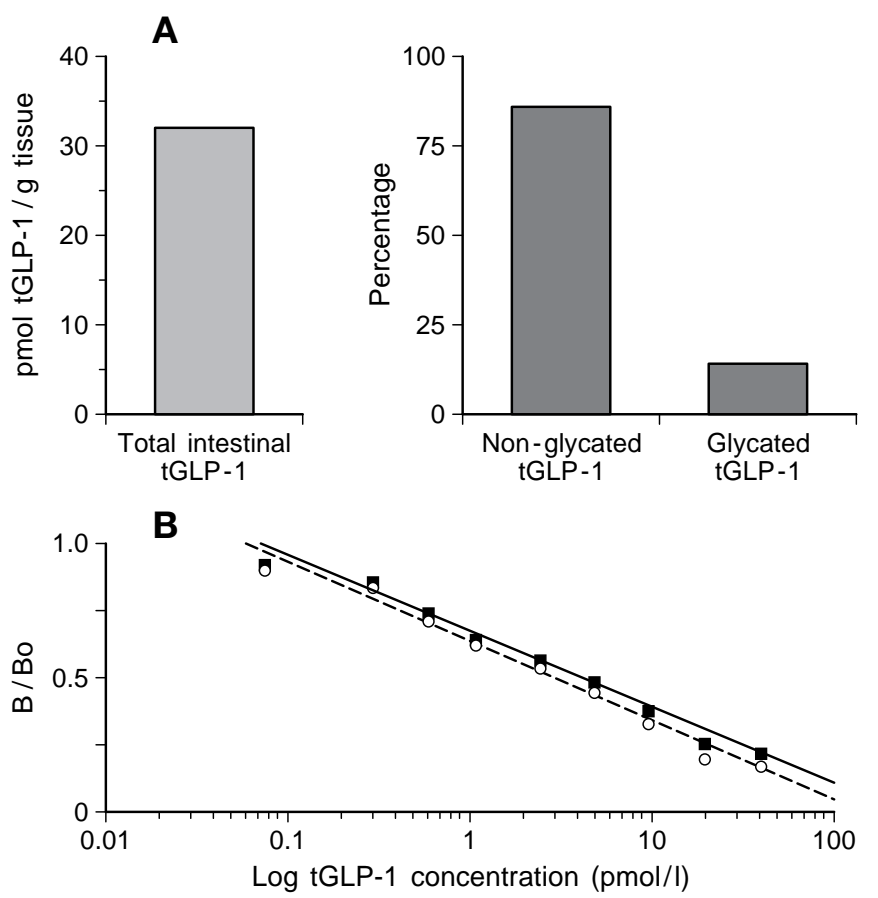

Fig. 4. A Total tGLP-1 and percentage glycated and non-glycated tGLP-1 in intestines. Pooled intestinal extracts from 4 animals were used. Values are means of 6 separate determinations. (B) Crossreactivity of the 2135 antiserum with tGLP-1 $(\square)$ and glycated tGLP-1 $(\bigcirc)$. Values are bound/bound with no antigen $\left(\mathrm{B} / \mathrm{B}_{\mathrm{o}}, n=3\right)$ versus $\log _{10}$ antigen concentration

that tGLP-1 stimulates insulin secretion more strongly at 5.6-11.1 mmol/l glucose compared with more extreme hyperglycaemic conditions (at $16.7 \mathrm{mmol} / \mathrm{l}$ ). The mechanism underlying the action of high glucose is unclear, but the observations indicate that the beta cell is well equipped to respond to tGLP-1 according to fluctuations of glucose within a restricted physiological concentration range.

This study has demonstrated that tGLP-1 can be glycated by exposure to hyperglycaemic conditions in vitro. The inclusion of the reducing agent sodium cyanoborohydride enabled conversion of the labile Schiff base intermediate into a highly stable glucitol adduct which could then be purified by RP-HPLC and used in the secretory studies. It has also been shown that glycation of tGLP-1 occurs naturally within the endocrine L-cells in the glucose-rich and highly vascularized environment of the intestinal tract. Indeed, data obtained in this study suggest that glycated tGLP- 1 represents as much as $14 \%$ of the total intestinal tGLP-1 content. This observation is paralleled by recent experiments which have established that both insulin and proinsulin are rapidly glycated in the beta cells in response to ambient glucose concentrations $[22,23]$. It is not feasible to quantify circulating glycated tGLP-1 due to the very low concentrations of tGLP-1 normally found in plasma $[2,4]$. It is notable, however, that glycated insulin is secreted 
from beta cells in vitro and circulates at high concentrations in hyperinsulinaemic ob/ob mice [23, 37].

Purification of glycated tGLP-1 by RP-HPLC followed by PD-MS and Edman degradation established that only the amino terminal $\mathrm{His}^{7}$ was glycated. Evaluation of the insulin releasing potency of monoglycated tGLP-1 showed that glycation at this $\mathrm{His}^{7}$ site resulted in up to a $73 \%$ decrease in activity compared with native non-glycated tGLP-1. An aminoterminal blockage such as glycation could be expected to prevent the initiation of the Edman degradation of tGLP-1. It seems possible, however, in this case that the reagents used in this reaction (e.g. anhydrous TFA, $25 \%(\mathrm{v} / \mathrm{v})$ aqueous TFA, trimethylamine) can cause deglycation such that the reaction can proceed even though the PTH-derivative of His is not formed.

Previous structure-function studies of GLP-1 have indicated the importance of amino and carboxyl terminal regions for the insulinotropic action of this peptide [38-40]. It has been found with the perfused rat pancreas that tGLP-1 and very high concentrations of GLP-1(1-36)amide stimulated insulin secretion, whereas the $\mathrm{NH}_{2}$-terminally modified GLP1(6-36)amide and GLP-1(8-36)amide did not [38]. Other studies with perfused rat pancreas [40] demonstrated that the non-amidated GLP-1(7-37) had a similar insulinotropic potency to tGLP-1 whereas GLP1(7-34) was less potent and both GLP-1(7-33) and GLP-1(8-37) were ineffective. In contrast to these studies, it has recently been reported that amino acid substitution at position 8 with either Gly or $\alpha$-aminoisobutyric acid, but not Thr or Ser, did not decrease the insulin-releasing potency of $1 \mathrm{nmol} / 1 \mathrm{tGLP}-1$ in the isolated perfused porcine pancreas [41].

Receptor binding characteristics of tGLP-1 analogues have also been examined by systematic exchange of each amino acid in the primary structure with L-alanine [39]. This comprehensive study found that His ${ }^{7}, \mathrm{Gly}^{10}{ }^{10} \mathrm{Phe}^{12}, \mathrm{Thr}^{13}$ and $\mathrm{Asp}^{15}$ are directly involved in receptor recognition and that $\mathrm{Phe}^{28}$ and $\mathrm{Ile}^{29}$ are important for tGLP-1 to adopt the conformation recognised by the receptor [40]. Substitution of the penultimate amino acid (position 8) in tGLP-1 with either Thr or Ser (but not Gly or $\alpha$-aminoisobutyric acid) also decreased GLP-1 receptor binding affinity [41]. These observations together with data from our study indicate that the amino terminal region of tGLP-1 is very important for the insulinotropic activity of the peptide and that glycation of $\mathrm{His}^{7}$ is sufficient to cause a substantial decrease in potency. Some preliminary data have indicated that glycated tGLP-1 is more resistant than tGLP-1 to dipeptidypeptidase IV degradation in blood plasma [42]. This observation suggests that the overall activity of glycated tGLP-1 in vivo could be a balance between decreased biological activity due to N-terminal modification and prolonged half-life which would tend to increase its insulinotropic action.
The finding that tGLP-1 can be glycated and that such structural modification greatly decreases insulinotropic activity raise a number of issues regarding the physiology, pathophysiology and possible therapeutic use of tGLP-1. More detailed studies are required to determine the extent of glycation of tGLP1 in the intestine and circulation in normal and diabetic states. In addition the possibility that N-terminally modified tGLP-1 could be useful in diabetes therapy requires investigation [41]. Glycation of tGLP-1 at the amino terminus as described in this study, in addition to decreasing insulin secreting potency, could also influence the half-life of the circulating tGLP-1 by protecting it from dipeptidyl peptidase IV (EC 3.4.14.5) [41, 43]. This enzyme gives rise to GLP-1(9-36)amide [41, 44] which exhibits a substantial decrease in insulinotropic activity $[45,46]$.

Acknowledgements. We thank Professor P. Højrup, University of Odense, Denmark, for carrying out the molecular mass determination on tGLP-1 and glycated tGLP-1. Dr. A.C. Boyd and Mr. A. Lawlor are thanked for their assistance with measurements of glycated tGLP-1. These studies are supported by Department of Health and Social Services (Northern Ireland).

\section{References}

1. Creutzfeldt W, Ebert R (1985) New development in the incretin concept. Diabetologia 28: 565-573

2. Fehmann H-C, Göke R, Göke B (1995) Cell and molecular biology of the incretin hormones glucagon-like peptide-1 and glucose-dependent insulin releasing polypeptide. Endocr Rev 16: 390-410

3. Holst JJ, Ørskov C (1994) Glucagon and other proglucagon-derived peptides. In: Walsh JH, Dockray GJ (eds) Gut Peptides Biochemistry and Physiology, Raven Press Ltd., New York, pp 305-340

4. Goke B, Goke R, Fehmann H-C, Bode H-P (1996) Physiology and pathophysiology of GLP-1. In: Lefèbvre P J (ed) Glucagon III, Springer-Verlag, Berlin, pp 275-309

5. Nauck M (1996) Therapeutic potential of glucagon-like peptide 1 in type 2 diabetes. Diabet Med 13:S39-S43

6. Hvidberg A, Nielsen MT, Hilsted J, Ørskov C, Holst JJ (1994) Effect of glucagon-like peptide-1 (proglucagon 78-107amide) on hepatic glucose production in healthy man. Metabolism 43: 104-108

7. Villanueva-Peñacarrillo ML, Alcántara AI, Clemente F, Delgado E, Valverde I (1994) Potent glycogenic effect of GLP-1(7-36)amide in rat skeletal muscle. Diabetologia 37: 1163-1166

8. Fürnsinn C, Ebner K, Waldhäusl W (1995) Failure of GLP1(7-36)amide to affect glycogenesis in rat skeletal muscle. Diabetologia 38: 864-867

9. Nauck MA, Holst JJ, Willms B, Schmiegel W (1997) Glucagon-like peptide 1 (GLP-1) a new therapeutic approach for type 2-diabetes. Exp Clin Endocrinol Diabetes 105: 187-194

10. O'Harte FPM, Gray AM, Abdel-Wahab YHA, Flatt PR (1997) Effects of non-glycated and glycated glucagon-like peptide-1(7-36)amide on glucose metabolism in isolated mouse abdominal muscle. Peptides 18: 1327-1333

11. Gutniak M, Ørskov C, Holst JJ, Ahrén B, Efendic S (1992) Antidiabetogenic effect of glucagon-like peptide 1 
(7-36)amide in normal subjects and patients with diabetes mellitus. New Engl J Med 326: 1316-1322

12. Göke R, Trautmann ME, Haus E et al. (1989) Signal transmission after GLP-1(7-36)amide binding in RINm5F cells. Am J Physiol 257:G397-G401

13. Fehmann HC, Habener JF (1991) Homologous desensitization of the insulinotropic glucagon-like peptide-1(7-37) receptor on insulinoma (HIT-T15) cells. Endocrinology 128: $2880-2888$

14. Wheeler MB, Lu M, Dillon SJ, Leng XH, Chen C, Boyd III AE (1993) Functional expression of the rat glucagon-like peptide-1 receptor, evidence for coupling to both adenylyl cyclase and phospholipase C. Endocrinology 133: 57-62

15. Clark SA, Burnham BL, Chick WL (1990) Modulation of glucose-induced insulin secretion from a rat clonal cell line. Endocrinology 127: 2779-2788

16. Göke R, Conlon JM (1988) Receptors for glucagon-like peptide-1(7-36)amide on rat insulinoma-derived cells. J Endocrinol 116: 357-362

17. Lankat-Buttgereit B, Göke R, Stöckmann F, Fehmann HC, Göke B (1994) Detection of the human GLP-1(7-36)amide receptor on insulinoma-derived cell membranes. Digestion 55: 29-33

18. Thorens B, Porret A, Bühler L, Deng S-P, Morel P, Widmann C (1993) Cloning and functional expression of the human islet GLP-1 receptor: demonstration that exendin4 is an agonist and exendin-(9-39) antagonist of the receptor. Diabetes 42: 1678-1682

19. Ørskov C, Poulsen SS (1991) Autoradiography of rat tissues with GLP-1. Diabetes 40: 1292-1296

20. McClenaghan NH, Barnett CR, Ah-Sing E et al. (1996) Characterization of a novel glucose-responsive insulin-secreting cell line, BRIN-BD11, produced by electrofusion. Diabetes 45: 1132-1140

21. O'Harte FPM, Højrup P, Barnett CR, Flatt PR (1996) Identification of the site of glycation of human insulin. Peptides 17: 1323-1330

22. Abdel-Wahab YHA, O'Harte FPM, Ratcliff H, McClenaghan NH, Barnett CR, Flatt PR (1996) Glycation of insulin in the islets of Langerhans of normal and diabetic animals. Diabetes 45: 1489-1496

23. Abdel-Wahab YHA, O'Harte FPM, Barnett CR, Flatt PR (1997) Characterization of insulin glycation in insulin-secreting cells maintained in tissue culture. J Endocrinol 152: 59-67

24. Roepstorff P (1993) 252-Californium plasma desorption time-of-flight mass spectrometry of peptides and proteins. Methods Mol Biol 17: 229-235

25. O'Harte FPM, Bockman CS, Abel PW, Conlon JM (1991) Isolation, structural characterization and pharmacological activity of dog neuromedin U. Peptides 12: 11-15

26. Flatt PR, Bailey CJ (1981) Abnormal plasma glucose and insulin responses in heterozygous lean $(\mathrm{ob} /+)$ mice. Diabetologia 20: $573-577$

27. Shima K, Hirota M, Ohboshi C (1988) Effect of glucagonlike peptide-1 on insulin secretion. Regul Pept 22: 245-250

28. Komatsu R, Matsuyama T, Namba M (1989) Glucagonostatic and insulinotropic action of glucagon-like peptide1(7-36)-amide. Diabetes 38: 902-905

29. Weir GC, Mojsov S, Hendrick GK, Habener JF (1989) Glucagon-like peptide-1(7-37) actions on endocrine pancreas. Diabetes 38: 338-342

30. Drucker DJ, Philippe J, Mojsov S, Chick WL, Habener JF (1987) Glucagon-like peptide-1 stimulates insulin gene expression and increases cyclic AMP levels in a rat cell line. Proc Natl Acad Sci USA 84: 3434-3438
31. Lu M, Wheeler MB, Leng XH, Boyd III AE (1993) The role of the free calcium level in $\beta$-cell signal transduction by gastric inhibitory polypeptide and glucagon-like peptide-1(7-37). Endocrinology 132: 94-100

32. Yada T, Itoh K, Nakata M (1993) Glucagon-like peptide1 (7-36)amide in adenosine 3 ', 5 '-monophosphate increase cytosolic free $\mathrm{Ca}^{2+}$ in rat pancreatic $\beta$-cells by enhancing $\mathrm{Ca}^{2+}$ channel activity. Endocrinology 133: 1685-1692

33. Gromada J, Dissing S, Bokvist K et al. (1995) Glucagonlike peptide 1 increases cytoplasmic calcium in insulin secreting beta-TC3-cells by enhancement of intracellular calcium mobilization. Diabetes 44: 767-774

34. Holz IV, Kuhtreiber WM, Habener JF (1993) Pancreatic beta-cells are rendered glucose-competent by the insulinotropic hormone glucagon-like peptide-1(7-37). Nature 361: 362-365

35. Rachmann J, Gribble FM, Barrow BA, Levy JC, Buchanan KD, Turner RC (1996) Normalization of insulin responses to glucose by overnight infusion of glucagon-like peptide1(7-36)amide in patients with NIDDM. Diabetes 45: $1524-1530$

36. Kawai K, Suzuki S, Ohashi S (1989) Comparison of the effects of glucagon-like peptide-1(1-37) and glucagon-like peptide-1(7-37) and glucagon on islet hormone release from isolated perfused canine and rat pancreases. Endocrinology 124: 1768-1772

37. Flatt PR, Abdel-Wahab YHA, Boyd AC, Barnett CR, O'Harte FPM (1996) Pancreatic B-cell dysfunction and glucose toxicity in non-insulin-dependent diabetes. Proc Nutr Soc 56: 243-262

38. Suzuki S, Kawai K, Ohashi S (1989) Comparison of the effects of various $\mathrm{C}$-terminal and $\mathrm{N}$-terminal fragment peptides of glucagon-like peptide 1 on insulin and glucagon release from isolated perfused rat pancreas. Endocrinology 125: 3109-3114

39. Mojsov S (1992) Structural requirements for biological activity of glucagon-like peptide-1. Int $\mathrm{J}$ Peptide Protein Res 40: 333-343

40. Adelhorst K, Hedegaard BB, Knudsen B, Kirk OD (1994) Structure activity studies of glucagon-like peptide-1. J Biol Chem 269: 6275-6278

41. Deacon CF, Knudsen LB, Madsen K, Wiberg FC, Jacobsen O, Holst JJ (1998) Dipeptidyl peptidase IV resistant analogues of glucagon-like peptide-1 which have extended metabolic stability and improved biological activity. Diabetologia 41: 271-278

42. Mooney M, Kelly CMN, Flatt PR, O'Harte FPM (1998) Aminopeptidase resistant glycated glucagon-like peptide1(7-36)amide shows potent insulinotropic action in vivo. Diabetologia 41: A183 (Abstracts)

43. Kieffer TJ, McIntosh CHS, Pedersen RA (1995) Degradation of glucose-dependent insulinotropic polypeptide and truncated glucagon-like peptide-1 in vitro and in vivo by dipeptidyl peptidase IV. Endocrinology 136: 3585-3596

44. Deacon CF, Johnsen AH, Holst JJ (1995) Degradation of glucagon-like peptide-1 by human plasma in vitro yields an N-terminally truncated peptide that is a major endogenous peptide in vivo. J Clin Endocrinol Metab 80: 952-957

45. Gefel D, Hendrick GK, Mojsov S, Habener J, Weir GC (1990) Glucagon-like peptide-1 analogs: effects on insulin secretion and $3{ }^{\prime}, 5^{\prime}$-monophosphate formation. Endocrinology 126: 2164-2168

46. Grandt D, Sieburg B, Schimiczek M et al. (1994) Is GLP1(9-36)amide an endogenous antagonist at GLP-1 receptors. Digestion 55: 302 (Abstract) 